\title{
Korean Picture Brides in Hawaii: Historical and Literary Narratives
}

\author{
Younho $\mathrm{OH}$ \\ Ewha Womans University, Seoul, South Korea
}

\begin{abstract}
Korean "picture brides" who migrated to Hawaii a century ago are reborn in stories through literary works produced in 21 st-century Korea and the USA. The literary value of picture bride stories is an important starting point for raising awareness of the reality of Korean migration to the US a century ago and for understanding the status of the 20th-century Korean diaspora beyond national borders and cultural boundaries. This study aimed to investigate the historical background of picture brides in Hawaii in the early 20th century so as to research that the life of Korean picture brides was much harder than those of other Asian picture brides. The stories of picture brides, gleaned from various oral narratives, news articles, poems, plays, and novels, not only represent in great detail the patriarchal and nationalistic discourse prevalent in the period in the US on Korean and Asian picture brides, but also provide important details on these women's daily living, independent efforts to make new lives in Hawaii, and the transboundary hybrid culture that emerged as a result. The comparative-literary approach of the study also captures the value of the transnationalist thread in the literary works under study.

Keywords: picture brides, Hawaiian history, Korean diaspora, literary transnationalism, Your Paradise, Song of the Wind, Honolulu (Picture Bride Jin), Arirang
\end{abstract}

\section{Korean Picture Brides in Hawaii: Historical and Literary Narratives}

Korean picture brides who migrated to Hawaii a century years ago are being reborn in plays and novels in 21st-century Korea and the USA. An English-language play, Picture Bride, created by Da-Eun, a theater based in the New York area, was staged as the final performance of the season for "2012-2013 Open Stage," a program of theatrical performances planned and executed by the Korean Cultural Center in New York. The novel Honolulu (Korean title: Picture Bride Jin), written by an American writer named Alan Brennert and first published in English in 2009, was translated into Korean in 2014. Your Paradise, written by Jaehee Im in 2013, was selected as an excellent work for the world literature award of the Korean newspaper the Segye Ilbo (World Daily) in 2013. Gyeongsuk Park's Song of the Wind, which portrayed the life of a picture bride based on the author's experience as an immigrant in the US in the early 20th century, was published in 2015. A short story, The Picture Bride Bobae Park, by Jung-hee Oh, which portrayed the joys and sorrows in the life of a picture bride and evoked her sorrowful sensibility, was published in 2007 in a photo collection commemorating the 100th anniversary of the history of Korean immigration to the USA (Overseas Koreans Foundation, 2007, pp. 70-79).

Younho OH, Ph.D., Assistant Professor, Ewha Institute for the Humanities, Ewha Womans University, Seoul, South Korea. 
Picture marriage was a popular practice of arranged marriage in Hawaii (and elsewhere in the US) in the early 20th century between Asian male immigrant laborers and women from their home countries (mostly Japan, Korea, Okinawa, the Philippines, and China), facilitated by that modern technological artifact, the photograph. It was criticized as a primitive custom by Americans; however, it was a highly effective solution to help unwed male Asian immigrant laborers in Hawaii maintain connections to their traditional cultures and communities, and to settle down firmly in Hawaii. For Korean laborers, in particular, picture marriage also had the strong nationalist objective of helping achieve the independence of the country, which was then a Japanese colony, since even after migrating abroad producing Korean children to inherit the nation of "Joseon" was viewed by many as a duty.

The history of Korean immigration to the US officially began on January 13, 1903, with the arrival of 102 Korean people (men and women) in Honolulu on the steamer the SS Gaelic. In-Jin Yoon divides the period of major Korean immigration into three stages, the first of which spans from 1903 to 1924, at which point US immigration law prohibited Koreans from immigrating. A total of 7,226 Koreans (about 11\% of all Hawaiian laborers) immigrated to Hawaii as sugarcane plantation workers between 1903 and 1905. Considerable numbers of picture brides $(1,115)$ and students and other independence activists (541) immigrated between 1910 and 1924 (Yoon, 2004, pp. 202-203). During this period, Korea itself had to fight against the invasions of other neighboring empires, and many Korean people also suffered from great famines and natural disasters. In that period, the Korean government was forced to promote overseas labor migration to alleviate the situation in Korea. The Hawaiian Sugar Planters' Association (HSPA) was able to recruit Korean laborers, whose migration to Hawaii was facilitated by David W. Deshler, an American businessman, and Horace N. Allen (1858-1932), the Envoy Extraordinary and Minister Plenipotentiary of the United States of America to Korea (German N. Kim, 2005, pp. 300-301). The HSPA hired Korean laborers to replace the Japanese who were leaving for the west coast of the United States, demanding a high salary, and paid Korean laborers about $\$ 16$ per month like Japanese laborers, one-third of the salary of white laborers. HSPA also recruited picture brides as those workers' future wives and secured their admission into Hawaii as a means of avoiding the conflicts caused by unmarried male Asian laborers. Korean immigration to Hawaii in the early 20th century happened in a the context of the Korean government's inability to exercise political and military power under Japanese colonization, the severe poverty that the people had suffered for a long time and also the greed of Western capitalists, who strategically took advantage of poor laborers from poor and colonized countries; and the history of picture marriage in Hawaii reflects and demonstrates that the turbulent Korean history at the end of the Joseon dynasty unfolded in an organic relationship with(in) the world political-social-economic system, involving the US, China, and Japan, and by extension other countries beyond the boundaries of the Korean Peninsula and East Asia (Y. Lee, 2007, p. 26).

Against this background, we may ask why the stories of picture brides that were popular in the 20th century are being revived in this 21 st century? In previous work, I explained that many academic studies in the 1990s gave great insight into Koreans foreign migration, which began to spread all across the world in the early 20th century, producing a diaspora literature boom in Korea in the 2000s (Oh, 2017). In the process, Korea became a multiethnic and multicultural society; this phenomenon began with an interest in the identity of Koreans living outside the Korean peninsula and an effort to understand the lives of various foreign laborers living on the Korean Peninsula.

Another point whose importance cannot be overemphasized is that Korea was a Japanese colony at that 
time; therefore, Korean picture brides migrated and set up new lives in general in far more difficult circumstances than those from Japan. Diaspora novels allow us to enter life of the early 20th-century Korean diaspora and reconstruct the meaning of the lives of Korean women migrants especially, which have been effaced by macro-historical reigning interest in dominant ethnic and language groups, nations, classes, and the dominant gender. Further, they also reveal the true face of the imperialism that marketed destinations to laborers from poor and colonized countries with false, rosy promises while exploiting their labor when they arrived. The stories of picture brides in Hawaii also encapsulate the liminal status of Hawaii in the period, as a space of imperial boundaries, and the significance and the problematic nature of Asian women's immigration to the US in the early 20th century.

Taking a further step from Oh (2017), this study aims to investigate the historical background of Korean and to some degree other Asian picture brides in Hawaii in the early 20th century, and show that the lives of Korean picture brides were much more difficult due to their historical circumstances. In addition, the study aims to demonstrate that the patriarchal, nationalistic discourse found in a variety of oral narratives, news articles, poems, plays, and novels on picture brides has changed and is changing over the course of time, and further, to present the lives of the independent Korean migrant women of the 20th century and the diaspora identity and transboundary culture. In the process, this study examines works featuring "picture brides" as a theme from a comparative-literary perspective, and by doing so discovers the potential of transnationalism in literature for our understanding not only of these women's stories but of the broader relationship between the Japan, Korea, and the US.

\section{The Historical Background and the Tragedy of Korean Picture Brides}

Hawaii, an island chain in the middle of the Pacific Ocean, has long sat on the edge of an imperial zone based upon a smoothly functioning capitalist system that fosters labor-intensive industries viable in part on the basis of employing low-cost workers from developing countries (Oh, 2017). In short, Hawaii was a strategic hub where the businessmen of the empire could easily make money; as a result, many cultural and political conflicts unfolded as Hawaiian natives, white plantation owners backed by the US government, and laborers from Japan and Korea as well as China economically collided and mixed under the logic of capitalism from the late 19 th through the early 20 th century.

Starting in the $1830 \mathrm{~s}$, Hawaii was in need of many laborers as pineapple and sugarcane plantations developed rapidly. White plantation owners started bringing Chinese laborers from Guangdong, Hong Kong, and Macao, places suffering from overpopulation and war. Since 1852, Chinese people had started to work as laborers in Hawaii, and the population of Chinese people had naturally increased, filling in the gap left by native Hawaiians who had died from Western diseases since first contact. ${ }^{1}$ The US Congress legislated the racist Chinese Exclusion Act to stop Chinese immigration in 1882, and Chinese immigration declined as a result, as Japanese laborers replaced Chinese laborers. By around 1890, Japanese people accounted for $80 \%$ of the entire laborer population in Hawaii, and led strikes demanding higher wages and improved treatment. As the US strongly aspired to acquire Hawaii, and as the white plantation owners wanted to keep the workers from organizing effectively, they did not want any given ethnic group to dominate the labor force on plantations; nor

\footnotetext{
${ }^{1}$ Since the British explorer James Cook set foot on Hawaiian soil for the first time in 1778, countless Westerners have come to Hawaii, many of them permanently. The 800,000 (all native Hawaiian) population in 1778 shrank to 40,000 in 1878 due to the diseases these Westerners brought along with them (Fan, 1996, p. 71).
} 
did they wish to give up their greedy embrace of the ability to hire laborers at half price in Hawaii compared to California, for example, due to this influx. As a strategy to confound the Japanese laborers and keep the wages low, white plantation owners came to hire Koreans. Beginning with 102 Koreans, who left the Port of Incheon in December 1902 and arrived in Honolulu on January 13, 1903 on an American merchant ship, the SS Gaelic, a total of 7,226 Korean laborers had immigrated to Hawaii as contracted laborers in Hawaiian sugarcane plantations by 1905 (for comparison, approximately 180,000 Japanese arrived between 1885 and 1907).

Hawaii is often referred to as a paradise - these days, a dream vacation spot for the entire world, because of its natural attractions and unique local culture. However, Hawaii was much more than this for Koreans in the early 20th century. Advertisements for Hawaiian immigration recruitment in 1902 read: "The climate is mild all year around with no extreme heat or cold"; "Every island has a university. They teach English without charging any tuition"; "In any season of the year, it is easy to find a job year after year, and it is not hard at all for people with a healthy body and good conduct to obtain a stable long-term job under the general protection of the law"; and "A house, wood, drinking water, and medical expenses are provided by the hiring plantation owner" (G. Lee, 1979, p. 87). Together with the positive impression fostered by these advertisements, hearsay said that "Money grows on trees in Powa" (Hawaii). When Korean immigrants arrived in Hawaii, they instead found themselves working all day long in sugarcane fields for 16 dollarsas their monthly wage in 1905 . The welfare benefits they were promised to receive were not provided. Their dream of paradise was shattered into pieces within a few months, and they found themselves trapped in a hellish life, victims of the gap between the reality and the representation of the opportunities awaiting migrants to Hawaii (newspaper advertisements, recruiters and matchmakers, hearsay).

The second wave of Korean immigration to Hawaii took place between 1910 and 1924, and this time mainly consisted of picture brides $(1,115)$ and families of workers already present. As the law prohibited single Asian male immigrant laborers in the US from marrying American women, picture bride immigration took off as men were forced to search for brides from the home country. Issuance of US visas to Japanese (including Koreans) was banned under the "Gentlemen's Agreement" signed between Japan and the US in 1908, but the workers' families were allowed to enter the US; therefore, Japanese male workers were able to bring brides from Japan. Koreans also took advantage of this practice.

Despite the shared term "picture bride" and their status as women from the home country marrying male immigrant laborers in Hawaii who selected them through the medium of photographs, Japanese and Korean picture brides were very different from each other in terms of the meaning of their marriages, the marriage process, and their lives in Hawaii following marriage.

The strongest motivation for Asian picture brides to immigrate to Hawaii was economic. In Korea, people who could find no way to earn a livelihood and survive due to the extremely unstable political situation and the Japanese imperialist encroachment during the late 19th century through the early 20th century left for other places, such as Manchuria, Gando (Jiandao, a border area between Korea and China), Japan itself, and the US, including Hawaii. The husbands-to-be paid the cost-100 to 200 dollars - for picture bride to come to Hawaii; this was a great sum that a male laborer could only manage to save by working without spending for one or two

\footnotetext{
2 "1) The government of Japan does not issue passports for all labor workers except for the parents, wife, and children of residents residing in the mainland of the US in relation to recurring voyage.... 4) Hawaii is completely different, therefore, exempted. The government of Japan prohibits the voyage of all labor workers except for the existing voyagers, and the parents, wife, and children of residents in Hawaii for the time being." See Yu (2002, pp. 28-29).
} 
years.

For Japanese picture brides, the main motivation for entering into such a marriage was the recommendation of their families, who wanted picture brides to live well even though they went abroad. By contrast, Korean picture brides were often given a recommendation from a Christian missionary or pastor, and many of them opted for picture marriage to pursue the dream of escaping patriarchal Korea and receiving a modern education in America (Patterson, 2000, pp. 144-147). At the same time, many of these women were inspired by patriotism, choosing picture marriage in order to leave the Japanese colony of Chōsen and become actively engaged in the anti-Japan Korean independence movement (Kim, 2005, p. 348) based in the United States. Let us examine this state of affairs through life stories narrated by actual picture brides in Hawaii.

My parents did not allow me to play outside the house after I turned nine. The majority of girls found themselves in a similar situation like mine. Under these circumstances, I thought becoming a picture bride is the only way to break free from these restraints... I persuaded a friend to go to America with me, and searched for a matchmaker. I met Ms. Gyenam Lee from Busan, and my curiosity about picture brides started to grow rapidly from that moment.

My brother used to say: "I think it's necessary for young Korean women to go abroad and learn how to view other countries. It's not right to stay inside home just like a frog in a well. You can't learn how the society works." I was influenced by my progressive brother and decided to become a picture bride. (From an interview with Ms. Gyeyul Park; Kim, 2005, p. 348)

I secretly visited Ms. Park. I asked her to help me go to America as a picture bride. I wanted a further education in America. Finally, I received a picture of Yungyeong Lee, and he appeared to me very handsome. I corresponded with Yungyeong Lee through letters for a few months, and decided to marry him. Soon after, he sent me 50 dollars for the fare to come to America. At that time, 50 dollars was a huge amount of money. To go to the US, I purchased a new coat. But then, a distant relative strongly disapproved my marriage and my departure to the US saying "We must not have a woman in our family sold as a prostitute." My parents locked me up at home and harshly reprimanded me verbally as well as physically. Such punishment liberated me from the subtle guilt I had carried in my heart for secretly corresponding with him through the matchmaker. I felt much better after the punishment. The matchmaker wrote to my future husband that my face was covered with smallpox scars, but he replied in his letter that he would be happy with a woman as long as she can bear him many children and can manage the household well. (From an interview with Ms. Gyeman Lee; K. W. Lee, L. I. C. Kim, \& G. Kim, 2016, pp. 81-82)

As these interviews with Ms. Park and Ms. Lee show, some picture brides had an aversion toward the patriarchal culture of Joseon, and were progressive and of a mind to receive education in America, an advanced nation, actively seeking to become picture brides in order to carry this out. Meanwhile, they had to face the criticism that they were "women sold as prostitutes" for 50 dollars. This shows how negatively the mainstream society of that time viewed the culture of the picture bride.

According to Alice Yun Chai, the immigration experiences lived by Japanese, Korean, and Okinawan picture brides were different from one another in other ways as well. The majority of Japanese and Okinawan picture brides came from the same village as their husbands; by contrast, Korean picture brides came from different regions, far away from the native villages of their husbands; as a result, they underwent great difficulties in the course of their marriage life (Chai, 1988, p. 56). Most of the husbands were from the capital, Seoul, and most of the women were from the province of Gyeongsang-do (Patterson, 2000, p. 144). The two areas, 300 to 400 kilometers apart, differed in language and lifestyle from each other.

Criticism of picture brides rose in 1909 when an editorial defending "picture marriage" was published in the Sinhanminbo (Newspaper for the People of New Korea) by the Gukminhoi (Korean National Association), 
the Korean association based in San Francisco, arguing that picture marriage is an "inevitable choice for the survival of the people living abroad." On March 3, 1914, the Sinhangukbo (National Newspaper of New Korea) published a negative perspective of picture marriage, arguing that "Picture marriage faces resistance from two aspects: the first problem is its enormous expenses, and the other is the fact that it is an 'evil custom of Japanese people' that betrays the humane duty." In response to this, on March 25, 1915, articles supportive of picture marriage were published, under the following titles: "Reconsidering the problem of picture marriage" and "Understanding picture marriage." These articles encouraged picture marriage while criticizing jungmae gyelhon (arranged marriage) as a "big disaster for humanity." This standpoint indicates that picture marriage was encouraged merely because it was seen as better than the extinction of the people. As shown above, picture marriage was converted by the media to an issue of economic hardship, conflict within the Japanese empire, and national problems, beyond just personal problems (J. Kang, 2011, pp. 215-222). This perspective of the Korean media in the US influenced the colonized media in Korea, where picture marriage was represented as a business of "trading or selling women" (Maeilsinbo (Daily News, a bulletin of the Governor-General of Korea), March 6, 1915) rather than a happy marriage. Jingu Kang points out that this criticism originated from the patriarchal system of the time, aiming to criticize the vanity of women who looked favorably towards picture marriage (2011, p. 222) - since at that time, Korean society believed that women should only live at home, and thought that women were educated or immigrated to the United States because of the vanity of women.

In another major difference, Japanese male laborers generally returned to Japan in person to look for a bride in their hometown or to be introduced to a future bride through a nakōdo or matchmaker: a relative such as an aunt or uncle or a family friend. They then came back to Hawaii as a couple to get married. It was a "marriage between 'families' like a typical arranged marriage," and a decision about their marriage was made after the parties sufficiently learned about each other's family circumstances (Yanagisawa, 2007). According to Ikumi T. Yanagisawa, Japanese picture brides generally had a traditional wedding ceremony in Japan and listed their names in the family register of the husband. After arrival in the US, they attended an American marriage ceremony and confirmed their marital status by signing a written wedding vow. In contrast, Korean picture brides did not have a wedding ceremony, and crossed the ocean to Hawaii as a "wife" without any marriage registration under the civil law (Seo, 2011, p. 105). Initially, husbands came to Hawaii with a Korean passport; after the Korean colonization of Japan in 1910, the photo brides came to Hawaii with a Japanese passport. Therefore, photo marriages between Koreans were placed in a complex legal condition where it was unclear who could be held accountable. Picture brides also arrived from the Philippines, but they lived in Hawaii as American citizens because their home country was an American colony at that time. Compared to them, the legal status and social conditions of Korean picture brides, from their oppressed colony, was extremely deplorable.

Unlike the Japanese picture brides, whose arrival in port was generally fairly straightforward, Korean picture brides, who had not yet met their husbands, were often shocked when they saw their husbands' faces on the first day of arrival in the port, because the men looked much older than they had been in the pictures, and had been enervated by poverty and hard work. When sending their pictures to the colonized Korea, Korean male laborers very often exaggerated their financial status or sent photos taken when they were younger (for example, when they had just arrived in Hawaii). This distorted representation of reality clearly demonstrates the potential ill consequences of picture marriage mediated by photographs and the ill effects on these picture brides. 
One Korean woman, who became a picture bride through arrangement by her cousin, remembered:

I (Arinaga) saw him for the first time at the Immigration Station. He didn't look like his picture. He was really old.... My cousin in Honolulu arranged the marriage. I'm so disappointed, I cry for eight days and don't come out of my room. But I knew that if I don't get married, I have to go back to Korea on the next ship. So on the ninth day I came out and married him. But I don't talk to him for three months. (Fan, 1996, pp. 75-76)

Korean picture brides were often very active and assertive in deciding the conditions of their marriage and life in Hawaii. Such attitudes and actions played positive roles in their adaptation to a foreign culture and life in Hawaii. Korean picture brides worked unceasingly to survive extreme poverty and patriarchal home environments, and were actively engaged in church events and social gatherings for their children's education and the independence of Korea (Chai, 1988, p. 56).

Thus, Korean picture brides were refugees of a sort, who had fled colonial Chōsen, and also an ethnic minority who had to face the class conflict with various other ethnic groups in Hawaii. The historical background presented and firsthand accounts in the interviews excerpted in this section clearly show that the lives of Korean picture brides in the early 20th century were much more difficult than those from other countries. These kinds of historical stories, fictionalized, exerted a great influence on the basic plot of the picture bride stories.

\section{A Genealogy of Picture Bride Literature in Korea}

Literary works about Korean immigration to Hawaii and the rest of the US date back to the decade of the 1900s. Some representative examples include Songroigeum (1908), a novel by Jeongsu Yuk that criticized the anti-humanitarian treatment of the Hawaii migration process around 1905; Destiny (1920), a play by Baeknam Yun that portrayed a tragically failed picture marriage during this period; and To Catch a Cloud (1935), a novel by Yoseop Joo that portrayed a protagonist who immigrated to Mexico to work for three years as a slave with a stigma, and then escaped to the United States and lived the life of a member of the classes.

The story of Songroigeum ends with a scene in which a family who wished to emigrate to Hawaii because of the crisis of the time during the Russo-Japanese War (largely fought on the Korean peninsula) complete their physical examination in Japan. This story successfully portrays the political difficulties and economic hardships of that time, when many Koreans felt forced to emigrate to other countries; however, this work does not describe picture brides explicitly, and it is hard to discuss it in depth, as it is an incomplete story. On the other hand, the picture brides in Destiny and To Catch a Cloud are classic examples of female protagonists in melodrama; in Destiny, Mary becomes a picture bride in Hawaii because her father was misled by a matchmaker's proposal. She runs into Suok, her former sweetheart, who came to Hawaii searching for her. Mary's husband, Gilsam, finds out about the relationship between the two and attacks Suok with a knife. Mary, who tries to stop him, kills him. At the end of the story, Suok stays in Hawaii, to be with the jailed Mary at all cost. To Catch a Cloud considers the issue of picture marriage from the perspective of a male laborer. The main character, Junsik, after escaping from Mexico and going to the United States, wants a picture bride to settle with him, so he abstains from drinking and women, and studies the Korean alphabet (the Hangeul) to improve himself and exchange international letters with a photo bride. His picture bride, Sunae, had believed that the US was a "country loaded with money," a land where "everybody becomes a millionaire as soon as one steps on the American soil" (Joo, 2015, p. 199). When she arrives, she is obsessed with the fact that she was deceived, and does not pay any attention to Junsik, who had hoped to start a new life with her. She cheats on him with 
another man, named Indeok; she leaves Junsik, and he ends up murdering her boyfriend (Kang, 2011, pp. 220-222). In both these melodramatic works, picture husbands are extremely sensitive to the chastity or infidelity of their wives, and eventually one of the men involved dies in a murder of passion. Thus, they portray a negative impression of picture brides as "trouble" from a patriarchal viewpoint.

This male-dominated viewpoint persists in Arirang, written by Jung-rae Jo in the 1990s. Until this novel was published, few novels written about picture brides were published. Arirang is a long saga of 12 volumes each over 300 pages, a novel that depicts the history of the Korean diaspora with detailed descriptions of the spread of the Korean ethnic community (Kang, 2009, p. 8). Centering around the Mangyeong Plain ${ }^{3}$ in Korea, which was most severely hit by the economic pillages of the Japanese, this novel portrays in great detail how Korean people were trampled by Japanese oppression and how many of them left for other places, such as Manchuria, Gando/Jiandao, Japan, ${ }^{4}$ and Hawaii. Most of all, this work portrays the story of Korean immigration to the US in greater detail than any other literary work. Due to family debt, Yeonggeun Bang, the eldest son of Madame Gamgol, volunteers to join candidates for immigration to the US recruited by the Daeryuk Sinmin Company ("Company for the New Citizens of the Continent"), and moves to Hawaii to work and earn money to pay down what is owed. In sugarcane and pineapple plantations, his life is similar to that of a slave. Over time, he overcomes conflicts with plantation owners and settles permanently in Hawaii, eventually establishing a school and conducting combat training of fighters for the independence of Korea. He creates and sings a folk song or work song, "Arirang," with the lyrics, "Hawaii the American land is my foe," which brings comfort to his painful life and reinforces his sense of the unity of the Korean nation.

Picture bride stories are depicted as one of many episodes of Koreans immigrating to the USA in Arirang. Another bride, Malnyeo, comes to Hawaii for a picture marriage, but soon runs away from her husband because he is too old, not like the man she saw in the picture. Yongseok Nam, who had not yet found a picture bride, rescues and marries her. Malnyeo liked motion pictures and longed for American culture and America. The pastor she followed suggested that she could go to America as a photo bride. She hates working on the plantation, and tries to make money by a desk job, as a social activity, becoming actively engaged in the Gukminhoi (Korean National Association, a Korean independence society) ${ }^{5}$ and church events, but she gets mistreated by her husband and ostracized by other picture brides because of the prejudice that women still have to work at home. The novel repeatedly highlights the fact that the need for picture brides is interwoven with the political goal of the Gukminhoi: to work for the independence of Korea by bringing Korean women to marry male migrant workers and stabilize their lives and their homes so as to expand and consolidate the Dongpo society (a Korean expatriate group) and eventually establish a headquarters for the independence movement. In these literary works, which aimed to both perpetuate a patriarchal system and create an independent nation, picture brides are depicted as selfish, vain women who deny the traditional lifestyle, long for American culture, and often cheat on their husbands - in short, who fail to fulfill the political role set out for them.

It is not until the 1980 s that true stories of picture marriage were told from actual picture brides' perspectives, based on their experiences and memories of fleeing from male and Japanese oppression at home

\footnotetext{
${ }^{3}$ Mangyeong Plain is Korea's breadbasket, and produced a huge amount of rice that was taken to Japan during the colonial period.

${ }^{4}$ In contrast to the other locations mentioned, most Koreans who left for Japan did so non-voluntarily, as conscripts and later also as "comfort women" for the Japanese military during World War II.

${ }_{5}$ Historically, the first Korean picture bride was Sara Choi; she married the leader of the Gukminhoi, Naesu Lee. The novel seems to have borrowed these historical facts for the character called Malnyeo.
} 
to lead an independent life. These stories were rediscovered by writers who came into contact with the original oral stories in the process of analyzing the lives and voices of Korean immigrants to Hawaii and the continental US as historic data, folk "life histories."

In 1983, the publication of Picture Bride (Sajin Sinbu in Korean) Cathy Song's collection of poems about picture brides, attracted members of the Korean-American community and researchers of ethnic minority literatures. Song, whose grandfather was a first-generation immigrant and a picture bride in Hawaii, preserved and expressed her identity as "a third-generation Hawaii immigrant" in her book. Song's poems are exotic mélanges of Eastern and Western sensibilities, romantic representations of the history of the Korean people, a family history spanning three generations of immigrants and their descendants in Hawaii, and their experience settling in the US. In this regard, her work finely expresses the transnationalism and dynamic independence in the American immigrant literature, and discovers a new otherness in the mixture of Asian culture that she has not directly experienced and American culture that she was born and grew up in (Lee, 2015, p. 248). The title poem, "Picture Bride," expresses the emotions of a picture bride leaving her hometown behind and her bafflement at encountering her husband for the first time. After describing a male laborer who waits all night looking at the picture of his bride-to-be, and the moment when the picture bride steps onto the dock, looks at her groom, and finds out he is 13 years older than she is, Song poses a question: "Did she politely untie / the silk bow of her jacket / her tent-shaped dress?"; evidently, she foresees that their life together would not always be smooth.

In 2007, a considerable number of works portrayed picture brides as the main characters and focused on their lives. The Picture Bride Bobae Park, a short story by Jung-hee Oh, represented elements of the life of a real picture bride in the context of a fictional story, and conveyed the significance of Park's life through the uniqueness of the emotions experienced and the imagery used by Jung-hee Oh. The story begins with Ms. Bobae Park, nearly 80 years old, in a nursing home waiting for Jennifer, her great-granddaughter and a fourth-generation immigrant, who intends to set down her story in writing. Just as Cathy Song wrote poems based on her grandmother's memories of immigration to Hawaii, The Picture Bride Bobae Park exquisitely blends the recollections of the first-generation immigrant into the story written by her descendent. Ms. Park, who wanted to receive a modern education, decided to immigrate to Hawaii based on a missionary woman's advice. Looking at the picture of her husband, who was then "a young man of a high-collar hairstyle," whose handsome appearance led her to Hawaii, she recalls her weary life once she arrived, as she strived to survive and raise her children. His face, the first she encountered upon arrival in Hawaii, leaves her with the memory of "feeling like bursting into tears from the unfamiliarity and disappointment in his appearance," which had resembled "those of middle-aged men after a decade of physical labor in sugarcane fields," although he was still young. Ms. Park, after living through such experiences in Hawaii, finally realizes that some trace of her life will spread across the whole world through her children and their children; through the "memories of her children - who came into her life one after another — who helped her realize the meaning, value, and worth of her weary life with mysterious light like that of fireflies during a pitch-black night" (Foreign Koreans Foundation, 2007, pp. 78-79).

Thus, the mode of literary representation Song's and Oh's works is characterized by the memories and stories of first-generation picture brides in Hawaii. These works excellently convey the pain they experienced and their regret and as they look back at their own lives after doing their best to raise their children. Since many Korean women in Korea also had exhausting lives raising families under patriarchy, it is possible to gain a 
picture of a typical Korean woman's life in the 20th century, focused on surviving under patriarchy and raising a family.

Several longer novels - Your Paradise by Jaehee Im, Song of the Wind by Gyeongsuk Park, and Honolulu (Picture Bride Jinhei) by Alan Brennert — exhaustively portray manifold aspects of picture marriage: the birth and upbringing of the female protagonists who immigrate to Hawaii as picture brides, the stories of the male laborers in Hawaii who later receive the brides as their wives, their conflicts throughout their marriages, the achievement of Korean independence while the couples are busy raising their children, and the picture brides' reflections about their lives. These works comprehensively show the picture brides' political and economic context, as well as conflicts among picture brides, cultural conflicts between first- and second-generation immigrants, and conflicts among ethnic groups. The development of the stories is closely linked to the oral material provided by real picture brides in Hawaii (Lee \& Chang, 2014).

Your Paradise represents a wide spectrum of Korean women's life who crossed the ocean to settle in Hawaii. Ganghee and Nayeong lived together in one village and became photo brides. When they arrived in Hawaii, Nayeong proposed a husband-exchange to Ganghee because her betrothed, Sanghak, was too old for her, and Ganghee accepted it because the cost of giving up marriage and returning to Korea was too high. Ganghee marries Sanghak, but they are unable to love each other. One day, she is left behind when he joins the independence movement. Nayeong marries a businessman, Changseok, and lives happily for a while. When Changseok is diagnosed with leprosy, the US government forcibly divorces Nayeong and Changseok through the leprosy control law and let makes him go to a leper colony on the island of Molokai. She meets a new man, also a businessman, but he abandons her. Simyeong comes to Hawaii with her two daughters for avoiding husband's violence. She works hard for their success in Hawaii, but contracts a disease and dies. Sunrye is a lovely young lady. She marries an old man, but he dies soon after. She leaves Camp Nine (the residential quarter for Koreans in Honolulu) and returns as a "mudang", a Korean shaman who (in the novel) has received the revelation of heaven to prophesy or to heal the sick. Their diverse life in the novels takes place in an unfamiliar country, Hawaii, and in a mutual relationship with racially and culturally diverse people. This representation shows dynamism and hybridity of Hawaiian culture in the early 20th century.

Similarly, in Song of the Wind, Suhyang marries Gabjin, who physically abuses her, believing that she is cheating on him; they divorce each other for this reason. She meets Jangsu Han, a ginseng salesman, but he too leaves her, for the Provisional Government of the Republic of Korea. She lives through the Second World War with Samil (her son by Gabjin) and Christine (her daughter by Jangsu Han). The stories of picture brides thus explore the identities and meaning of picture brides' harsh and violent life. They try to find their own identity by experiencing the collapse of the pre-modern family system and enduring Hawaii's awful labor conditions and disorienting, culturally hybrid environment (Oh, 2017, p. 152).

Although the various protagonists of these two works are picture brides, the stories also bring to life the general history of Korean immigration to the US. As discussed earlier, Hawaii was a center of the Korean independence movement, and Your Paradise and Song of the Wind mainly revolve around protagonists involved in this movement. Sanghak in Your Paradise leaves Hawaii and travels around Manchuria and Korea delivering funds for the Independence Army. Gabjin in Song of the Wind returns to Korea to aid the cause, and dies during the March 1st Movement which was the anti-Japanese independence movement inaugurated on March 1, 1919.

Unlike these Korean-written picture bride stories, focusing on Korean people's national sentiment and 
identity, Honolulu, written by an American writer, portrays the life path of an ethnicminority woman within the context of the multicultural properties of the space of "Hawaii" and its transition from a premodern to modern stage. As the expression used in the novel, "melting pot" (Brennert, 2014, p. 462), suggests, Hawaii underwent various conflicts caused by the meeting of diverse ethnic groups from the 18th through the 20th centuries (and onward). Honolulu focuses on the life of Jin, a Korean woman who becomes an American citizen, and describes her progression to become a "true Hawaiian" as she learns to coexist with the people of other groups that she encounters. The story's metaphor for this is the "salad bowl"; in contrast to the melting pot, which highlights the convergence of conflicts and confusion into homogeneity, the salad bowl emphasizes an idyllic image of the cultural and ethnic variety of Hawaii, because such various ethnicities can create a meal that gives fullness and happiness with a variety of tastes and flavors.

This novel materializes a true understanding of Korean culture and tradition as it came to be in its minority role in Hawaii, through the character of Jin. In particular, the final scene reinterprets the life of Koreans in Hawaii as part of the multicultural mix by comparing it to a jogakbo, a Korean tablecloth made of scraps of fabric. ${ }^{6}$ Readers come to respect not only Jin herself, who overcame adversity and embraced a new culture in her own way, but also every ethnic minority person who has tried to coexist with other ethnicities and cultures in Hawaii over the past 100 years. In the final scene, Jin, who inherited her mother's talent in needlework, comforts herself for having lived a "life like a jogakbo," as her mother used to say-leaving Korea behind and living through vicissitudes, but also enriching experiences, in Hawaii. In the salad bowl and jogakbo metaphors, one can read the turbulence underlying these individual lives and the history of Hawaii and in a sense holding them together. The imagination of a beautifully embroidered jogakbo covering salad bowls is the author's consoling motif dedicated to the picture bride Jin. The novel re-emphasizes that coexistence with many foreign cultures is unlikely to be the fruit of deeply divided ideological interest, focus on economic gain, or extreme nationalism, but surely will be the outcome of the mindfulness and harmony created by the effort to live a sincere life on the part of every individual. The novel represents the triumph of micro-history (Jin's life as a jogakbo) in the face of macro-history (Korean people as a nation, and America as the state in which some of these Korean people live) (Oh, 2017, p. 157).

\section{Conclusion}

Stories of picture brides begin with a photograph. At times, they are depicted as the heart-broken protagonists in a tragic melodrama. They are also often portrayed as independent members of the Korean diaspora who realize the meaning of coexistence and the value of multiculturalism as a result of crossing boundaries of country, culture, ethnicity, and language. This study has taken a critical look at discourses that depict Korean women of the 20th century through distorted lenses based on imperialism, capitalism, patriarchy, and racism. Further, it has examined the transnationalist counterpoint to these discourses by looking at real and fictional stories of Korean picture brides in Hawaii and their dynamic identities.

\footnotetext{
${ }^{6}$ Jogakbo is also associated with the sujeojib (cutlery and chopsticks case) in The Picture Bride Bobae Park: "The colors of the threads expressing the sun, green mountain, flowing water, rock, cloud, pine tree, turtle, crane, and deer representing the eternal life embroidered on the spoon case still preserved their charm even after all these decades. However, with a close look, one could tell the yellowish stains here and there across the white silk" (p. 71). The protagonist Bobae believes they are "the teardrops of the mother who was praying for a good life and fortune for her son who was embarking an endless journey without a promise of return, the tears that she shed embroidering stitch after stitch under a dim light" (p. 72) It reminds us of the sorrowful efforts of picture brides who tried to protect their traditional culture and values in the alien land of Hawaii.
} 
Stories about picture brides offer a look at the vicious working conditions that the imperial capitalist imposed on these poor colonized souls. The novels draw the contours of their multifaceted lives as citizens, laborers, and aliens striving to survive on the edge of the empire. In this respect, their immigration can also be called "voluntary exile." Korean picture brides immigrated to Hawaii of their own volition. In the process, they engaged in multiple forms of resistance and establish families in order to establish their own identity (as a woman, a family member, a citizen of a country), and at times devoted great energy to the cause of the independence of their homeland. These real experiences are revitalized and preserved in ostensibly fictional stories of picture brides.

In these stories, Korean experience of transnational diaspora in the early 20th century, immigration to Hawaii, in the global world system, and the fictional imagination representing the emergence of modern diaspora and the modern values of citizens provides a problematic view on today's korean literature. Currently, many foreign laborers live in Korea. Like a hundred years ago, the world capitalist system has not changed, and labor migrants are being repeated. Therefore, Korean literature should seriously consider how to embrace them in Korean society and how to discribe them. I have been constantly trying to research the stories of Japanese photo brides and Filipino photo brides. Through that study, the literary imagination of a picture bride will show the possibility of transnationalist literature existing across countries, races, and cultures.

\section{References}

Brennert, A. (2014). Honolulu. Paju: Moonhaksuchub. (Sajin Sinbu Jini in Korean)

Chai, A. Y. (1988). Women's history in public: "Picture brides" of Hawaii. Women's Studies Quarterly, 16(1/2), 51-62.

Fan, C. C. (1996). Asian women in Hawai'i: Migration, family, work, and identity. NWSA Journal, 8(1), 70-84.

Im, J. (2013). Your paradise. Seoul: Namubench Publishing Company. (Dangsin-ui Paladaiseu in Korean)

Jo, J. (1994). Arirang. Seoul: Hainam. (Arirang in Korean)

Joo, Y. (2010). To catch a cloud. Seoul: Joeunchaek-Mandeulgi. (Guleumeul Jabeulyeogo in Korean)

Kang, C. (2009). A study on Korean-race diaspora demonstrated in Arirang, epic novel by Jo Jung-rae: Focusing on the diaspora of Korean emigrants to the US. Literary Criticism, 33, 7-30.

Kang, J. (2011). A study of the genealogy of the international marriage: Focusing on photograph marriage. Journal of Asian Women, 50(2), 211-236.

Kim, G. (2005). History of Korean immigration. Seoul: Pakyoungsa Publishing.

Lee, G. (1979). Immigration history of Korea. Seoul: Jungang New Books.

Lee, H. (2015). Double counterpoint of East and West: The poetry of Cathy Song. The Journal of East-West Comparative Literature, 32, 207-251.

Lee, K. W., Kim, L. I. C., \& Kim, G. (2016). Lonesome journey: Real history told of early Korean immigration to the American continents, from Hawaii to Yucatán and Cuba (Trans. E. T. Chang). Seoul: Korea University Press.

Lee, S., \& Chang, R. (2014). The growth of the Korean society in Hawaii 1903-1940. Seoul: Ewha Womans University Press.

Lee, Y. (2007). Early immigration settlements. In History of overseas Korean collection: History of Koreans in North America. Seoul: National Institute of Korean History.

Oh, Y. (2017). The boundary space of the Empire and the location of diaspora: Focused on Hawaii photo bride novels. The Journal of Modern Literary Theory, 68, 131-162.

Foreign Koreans Foundation. (2007). The 100-year-long whistle of the Gaelic: Photographic records of the history of Korean immigration to the U.S. over a century. Seoul: Hyunsillbook.

Park, G. (2015). Song of the wind. Seoul: Munidang Publishing Company.

Seo, H. (2011). Formation of cross-border marriage brokerage in Korea. Society and History, 99-131.

Song, C. (2007). Picture bride. New Haven: Yale UnivPr. (Sajin Sinbu in Korean)

Yanagisawa, I. T. (2007). Life histories of Japanese "picture brides" in Hawaii: From the first "picture brides" to the last. Treatises and studies by the faculty of Kinjo Gakuin University. Studies in Social Sciences, 3(2), 134-138.

Yoon, I. (2004). The Korean diaspora: Migration, adaptation, and identity of overseas Koreans. Seoul: Korea University Press. 
Yu, G. (2002). American policy towards the Japanese immigrants in the United States of America. Daegu: Taeilsa Book Publishing.

Yuk, J. (2004). Songroigeum. Paju: Bumwoosa.

Yun, B. (2013). An anthology of Yun Baeknam. Seoul: Hyundaemoonhak. (Yunbaeknam Sunjib in Korean) 